\title{
Health Impact Assessment as an Essential Element of Environmental Law in the National Legal Order. Considerations on the Basis of International Law
}

\section{Ocena Odziaływania na Zdrowie jako niezbędny element prawa ochrony środowiska $w$ krajowym porządku prawnym. Rozważania na gruncie prawa międzynarodowego}

\author{
Maciej Pakowski ${ }^{\star}$ Anna Garus-Pakowska* \\ *Kancelaria adwokacka, ul. Piotrkowska 287/2, 90-003 Łódź, Poland \\ E-mail: mpakowski@wp.pl \\ **Uniwersytet Medyczny w Łodzi, Zakład Żywienia i Epidemiologii, \\ ul. Żeligowskiego 7/9, Łódź, Poland \\ E-mail (Corresponding Author): anna.garus-pakowska@umed.lodz.pl, \\ ORCID 0000-0002-1677-8146
}

\begin{abstract}
The purpose of this paper was to prove that the standards for environmental friendliness set out by international law require the states to carry out Health Impact Assessment (HIA) before implementation of public or private investments having a potential human health impact even if national legal systems do not require it. The analysis of both soft international law and treaty law, as well as the case-law of international courts and tribunals show that Environmental Impact Assessment (EIA) is the international law ius cogens.

At the same time the human right to information and protection of life and health are regarded as fundamental human rights. According to the authors it means that carrying out proper Environmental Impact Assessment without Health Impact Assessment is not possible. It would be contrary to the human right to information and the obligation of the authorities to provide citizens with active transparency mentioned by the Inter-American Court of Human Rights and with the principle of fair balance developed in the case-law of the similar European Court together with the objective on sustainable development adopted in Agenda 2030.

According to the authors Health Impact Assessment is an immanent and integral part of environmental impact and the possible absence of provisions in the national law requiring investors to carry out HIA where EIA is necessary, does not justify the failure to assess.
\end{abstract}

Key words: public health, health security, environmental security, human environment, human rights, health impact assessment, law

\section{Streszczenie}

Celem niniejszej publikacji było wykazanie, że wyznaczone przez prawo międzynarodowe standardy ochrony środowiska wymagają od państw przeprowadzania oceny oddziaływania na zdrowie przed realizacją inwestycji publicznej lub prywatnej, która mogłaby potencjalnie oddziaływać na zdrowie nawet wówczas gdy nie wymagają tego krajowe porządki prawne. Analiza zarówno miękkiego prawa międzynarodowego, jaki i prawa traktatowego oraz orzecznictwa międzynarodowych sądów i trybunałów wskazuje, że ocena oddziaływania na środowisko jest międzynarodowym prawem ius cogens. Równocześnie prawo człowieka do informacji oraz ochrony życia i zdrowia uznawane są za fundamentalne prawa człowieka. Oznacza to w ocenie autorów, że przeprowadzenie prawidłowej oceny oddziaływania na środowisko z pominięciem kwestii odziaływania na zdrowie człowieka nie jest 
możliwe. Byłoby sprzeczne z prawem człowieka do informacji, oraz z obowiązkiem rządów zapewnienia obywatelom aktywnej przejrzystości, o której wspomina Międzyamerykański Trybunał Praw Człowieka, czy z zasadą fair balance wypracowaną w orzecznictwie adekwatnego Trybunału w Europie oraz z celami zrównoważonego rozwoju przyjętymi w Agendzie 2030. Zdaniem autorów ocena oddziaływania na zdrowie jest immanentną i integralną częścią oceny oddziaływania na środowisko, zaś ewentualny brak w prawie krajowym przepisów nakładających na inwestora obowiązku przeprowadzenie oceny oddziaływania na zdrowie, tam gdzie istnieje konieczność przeprowadzenia oceny oddziaływania na środowisko nie uzasadnia zaniechania przeprowadzenia tej oceny.

Słowa kluczowe: zdrowie publiczne, bezpieczeństwo zdrowotne, bezpieczeństwo środowiskowe, środowisko człowieka, prawa człowieka, ocena wpływu na zdrowie, prawo

\section{Introduction}

According to the definition of WHO, Health Impact Assessment (HIA) means: a set of different procedures, methods and tools needed to assess the potential impact of investments, programmes or policies on health defined as a state of complete physical, mental and social wellbeing, not merely the absence of disease or infirmity (Goetheborg, 1999). The main purpose of HIA is to support decision-making regarding investments or strategy papers. Public health remains in the centre of interest of HIA. This procedure goes hand in hand with Environmental Impact Assessment and usually complements it. Though, it happens to operate independently complementing the set of documents needed for carrying out investments or implementing so called strategy papers - in accordance with the principle of sustainable development.

This publication is intended to demonstrate that environmental protection standards set out by international law require the states to carry out HIA before implementation of public or private investments having a potential human health impact even if national legal systems do not require it.

\section{Interdependence between healthy environ- ment and healthy humans}

The international community at institutional level notices both a clear correlation between healthy, unpolluted environment and a healthy man and a link between environmental change and its impact on human health. This is a multi-vector impact and essentially each impact on the environment can result in certain health problems - even in case of natural nuisance through dust emission into the atmosphere because of volcanic eruption. The impact can be both direct by the effect of ionizing radiation, suspended particulate matter or noise, and indirect, for example, when water conditions are affected influencing human health globally and locally.

The shrinkage of the Arial Sea caused by the construction of the irrigation system to water the Kuzyl

\footnotetext{
${ }^{1}$ HEAL (Health and Environment Aliance) - an international organization dealing with the dissemination of access to health care, health promotion, support for women and micro-donations in the field of health protection.
}

Kum desert with the water of this lake is a fine example of an investment with severe health repercussions. The investment resulted in the fast shrinkage of the lake, the increase of contaminant concentration (especially heavy metal and herbicides) and the change of the Mediterranean climate in the region in the desert one (Mall, Van Der Meer, Upshur, 2001). The whole region registered a dramatic increase in infant mortality which is the most visible health problem (Turkmenistan, Uzbekistan, Kyrgyzstan, Tajikistan, Kazakhstan) (Kiessling, 1998). Bełchatów Power Plant is a Polish example of an investment that may imply a negative effect to health due to emissions - as the report HEAL Poland notes ${ }^{1}$ - which are responsible for 1,270 of premature deaths, 359,200 of lost working days, 630 new cases of chronic bronchitis, 1,310 cases of hospitalization annually and charge the costs up to 3,45 million of Euros per year to the Polish healthcare system (Jensen, Staufler, Zander, Michalak, Puljic, 2020). Another example - fortunately considered to be of historic interest - is lead poisoning among children (over the period 1930-1980) living in the vicinity of Non-Ferrous Metals Works in Szopienice and in Miasteczko Śląskie (Upper Silesia) (Przybytek, 2015)². Any intrusion of environment has effects on human health. The effect may differ from close to longterm, direct to indirect and from short-term to farreaching ones. However, it is always a man who is finally affected in individual, holistic, social and species approach.

This fact, perceived from Agenda 2030 perspective, is of particular importance in view of the transformation of our world in the spirit of the principles of sustainable development. The objectives of Agenda have to take into account the fundamental principle of human dignity. This is about building the world with full respect for universal human rights, the rule of law, justice, equality and non-discrimination, irrespective of racial and ethnic background and cultural diversity; where there are equal opportunities allowing the human potential to be fully exploited and contributing to improve the shared wellbeing. Such

\footnotetext{
${ }^{2}$ The information about this epidemic is purely journalistic due to the information embargo imposed by the communist authorities of Poland on doctors who have made a medical diagnosis of the problem.
} 
reality can be created on one hand building the society with the right to information that efficiently exercises this right, and on the other hand without losing sight of concerns about protecting public and human health. Therefore, the objectives of Agenda are designed in such a way. The third objective focusing on assuring the health and promoting the well-being of people calls for the need to reduce perinatal and children mortality and also to eliminate communicable and non-communicable diseases. This goal cannot be reached without a public access to relevant information and without awareness on sustainable development expressed in objective 12 . This means that Health Impact Assessment within the meaning of Agenda is one of the non-codified but obvious methods of achieving its objectives (UN Resolution, 2015).

\section{Man vs. environment - observations in the context of international health policy}

\subsection{International Public Health Conferences about the correlation between health, environment and human rights}

The issue of the relationship between human and public health, environmental risks and the human right to health, healthy environment and health information was discussed on the international public health conferences under the auspices of WHO. They are an element of so called soft law. This means international standards not legally binding but showing certain legal value. These are different types of declarations, guidelines, recommendations and finally acts half stating political will. The legislation of soft law acts usually follows the development of treaty law (hard law) legally binding the state internationally.

International environmental law and global health protection law have their beginning in numerous soft law acts drawing attention to a strong correlation between public health issues, human health and the environment. The Stockholm Declaration (1972), which was the first, global document on environmental problems, has initiated that process. The declaration formulated 26 demands, three of which referred to the link between health and the environment, even though the concept of health was not anywhere to be directly mentioned (Stockholm, 1972). Then the following conferences organized under the auspices of WHO raised that issue: The Alma Ata Declaration (Alma-Ata, 1978), Ottawa Charter for health promotion (Ottawa, 1985), Adelaide Recommendations (Adelaide, 1988), Sundsvall Statement (Sundsvall, 1991), The Jakarta Declaration (Jakarta, 1997), The Ministerial Declaration concluding the fifth Conference of Public Health in Mexico (Mexico, 2000), The Bangkok Charter Health for all (Bangkok, 2005), The Helsinki Statement (Helsinki, 2013).
The abovementioned documents show that public health and health promotion are perceived as an enabling process to be made towards informed and consistent decision-making on everything that affects human health. This is possible only in civil societies. The governments should - according to the abovementioned documents - adopt clear control and settlement mechanism concerning health impact. They engender trust between the governments and their citizens.

The Rio Political Declaration on Social Determinants of Health (Rio, 2011) calls for commitment for promoting and facilitation of clear and inclusive decision-making process, for implementation of responsibility for health and for health management at all levels by an access to information and justice. It also calls for public participation, strengthening of the role of communities, increasing the civil society's contribution into developing and implementing policies by adopting measures to enable their effective participation in decision-making for reasons of public interest.

Having followed the international standards of the protection of human rights it should be assumed that an essential element of this right is that each person has the right to information and public participation in decision-making on projects having public health implications. This approach was explicitly presented in the Final Documents of the Conference in Adelaide, Sundsvall and Jakarta and in the Rio Declaration. The Adelaide Declaration notes that healthcare system cannot be created only for people but it should be developed with their help. That is why, citizens must be provided with an access to investment plans that may affect human health. People's opinion should also be respected in this matter. Standards of international law, set among others in the Universal Declaration of Human Rights, guarantee the right to information, the right to freedom of expression and the right to take public opinion into account. This objective can be achieved by adding health impact assessment to the environmental impact assessment procedure so that it could form its integral part.

\subsection{Health Impact Assessment in Gothenburg Con- sensus Paper}

So called Gothenburg Consensus Paper entirely focuses on Health Impact Assessment procedure (Goetheborg, 1999). It came about in Gothenburg in October 1999 with the participation of European Centre for Health Policy, Nordic School of Public Health, in cooperation with the European Commission and the participants from all over Europe. This paper defines HIA as a combination of the procedures, methods and tools by which policy, a programme or a project can be evaluated against the potential impact and the distribution of these impacts within the population. It also proposes the fixed aspects in HIA:

a) examining evidence concerning expected relationships between policy, a programme 
or a project and the health status of the population;

b) taking account of opinions, experience and expectations of people who may be affected by proposed policy, a programme or a project;

c) ensuring better understanding among decision-makers and the public of the influence of policy, a programme or a project on health;

d) proposals for adjustments/options to maximise positive and minimise negative impact on health.

Setting out the principles to be followed for HIA, the paper justifies that it must be an integral part of any process which influences or may influence human health. The process of HIA should start when there is a proposal, an intention to continue or modify the existing policy to reflect changes or launching new policy or a project. The process of HIA should be implemented soon enough to take into account the results before strategic and fundamental decisions. Defining the determinants of health, consensus indicates directly among others environmental factors which may have a health impact on the population. The document points out that HIA should be founded on democracy, therefore the right for people to participation in the transparent process of policy-forming, policy-implementation and policy-evaluation, which is one of its four basic values directly and indirectly affecting people's lives. It suggests that HIA in the meaning of Gothenburg Consensus Paper is functionally related to the right to life, health, a healthy environment, information and to the right to be heard. These are elementary human rights in the system of international human rights protection at global and regional level.

4. Health Impact Assessment as part of the right to a healthy environment in relation to the system of international human rights protection

The global system of human rights protection and regional systems establish the protection of fundamental right to life. This is stated in Article 3 which provides that everyone has the right to life, freedom and safety (Universal Declaration of Human Rights) (UDHR, 1948). It is repeated in the International Covenant on Civil and Political Rights, which in Article 6 recalls, that every human being has the inherent right to life (ICCPR, 1966). The regional systems of human rights protection also recognise it as a fundamental human right. Article 4(1) of the InterAmerican Convention on Human Rights stipulates that everyone's right to life shall be protected by law essentially from conception (ACHR San Jose, 1969). Banjul Charter (African Charter on Human and Peoples' Rights) shows in Article 4 that human beings are inviolable and every human being shall be entitled to respect for his life and the integrity of his person (Banjul Charter, 1981). The fundamental right to life of the European Convention for the Protection of Human Rights is cited as the first one in the catalogue of rights protected by this convention (Rome, 1950).

The right to health being considered in relation with the right to life is for the first time clearly mentioned in Article 25 of the Universal Declaration of Human Rights as the right to a standard of living adequate for the health and well-being (UDHR, 1948). This right is repeated in the International Covenant on Economic, Social and Cultural Rights, which obliged the parties to recognise the right of every human being to benefit from the highest, attainable standard of physical and mental healthcare (Article 12) (IPESCR, 1966). The right to the highest, attainable standard of health is defined as a human right and appears directly in the Constitution of the World Health Organisation. In Preamble we read: The enjoyment of the highest, attainable standard of health is one of the fundamental rights of every human being without distinction of race, religion, political belief, economic or social condition. The health of all people is fundamental to the attainment of peace and security and is dependent upon the fullest co-operation of individuals and States (New York, 1946).

General Comment of the Committee on Economic, Social and Cultural Rights No 14/2000 in the General Comment to Article 12 of the International Covenant on Economic, Social and Cultural Rights of 11 August 2000, indicates that the right to health is closely related and depends on implementation of other human rights including the rights to information and to freedom of expression. This comment recalls that the right to health includes a wide range of socio-economic factors promoting healthy living conditions. The right to health is also extended to health determinants such as the environment, eating and accommodation. The operative commission's interpretation of Article 12 (International Covenant on Economic, Social and Cultural Rights) indicates that public participation in decision-making related to human health at community, national and international level is an essential element of this right. This interpretation also defines the concept of the availability of information, which covers the right to search for, receive and impart information and ideas on health problems (UN Economic and Social Council Geneva, 2000).

The Inter-American Court on Human Right sees a close connection between the right to life, health, health environment and the right to information. In the advisory opinion it points out the existence of the obligation of active transparency for the state parties of the American Convention on Human Rights. This obligation includes providing environmental information and the environmental impact on human 
health ex officio in order that all citizens get universal, affordable and comprehensible access to it. In the Court's view the obligation of active transparency imposes on states an obligation to provide natural persons with the necessary information in order to ensure the full enjoyment of other human rights. This is particularly important as regards the right to life, physical integrity and health. Referring to public participation in decision-making, the Court indicated that it is one of the fundamental pillars of formal human rights because the participation allows an individual democratic control of the state. An individual can also question, examine and assess the compliance with public welfare. Therefore, public participation allows an individual to become a part of decision-making process and his or her opinions to be heard. In particular, public participation enables communities to hold their governments accountable for making decisions and improves the efficiency and credibility of government processes. The Court considers that public participation requires the implementation of the principles of transparency and disclosure and above all they should be supported by an access to information which enables public control by effective and responsible participation. In view of these considerations the Court has commented on local communities pointing out that the state is obliged to ensure the right to consultation and participation at all stages of planning and implementation of a project or an activity which may influence communities (...) or other rights. Therefore, the states must ensure that in addition to receiving and providing information all community members are fully aware of possible risks including health and environment threats to be able to issue a freely-given, informed opinion on each project which may affect their territory in the consultation process. The state must create continuous, trusted and effective channels for dialogue with the public, ensuring effective consultation and decision-making processes (Advisory Opinion, 2017).

The European Court of Human Rights under Article 8 of the European Convention on Human Rights (the right to privacy) developed the principle of fair balance, which assumes that there is freedom for the states to choose between environment protection and other social matters if the authorities issuing environmental decisions have fulfilled procedural requirements in assessing among others whether:

a) the investment process included the prior assessment of the impact on environment and human rights;

b) the public gets an access to adequate, environmental information;

c) interested community members could participate as decision-makers;

d) the right to freedom of expression and association has been respected.
It is pointed out that actions complementing retroactively the prior procedural shortcomings are prohibited because a contrario it would result in tolerating the ostensible nature of state's activity in these matters (Mowbray, 2010).

Affecting the fair balance gave rise to the judgement of the European Court of Human Rights on 24 January 2019 in Cordella et al v Italy, in which the Court found Italy responsible for the violation of the right to private and family life due to the air pollution resulting in smog.

Building up the principle of fair balance the European Court of Human Rights paid attention to a number of procedural, environmental obligations which could be aimed at guaranteeing the exercise of the right in accordance with the European Convention of Human Rights. This refers to the obligation to ensure sound and informed decision-making ((ECHR, 2004). As noted in the European jurisprudence this process has to involve appropriate researches and studies to foresee and assess in advance impacts which could cause serious damage to the environment and violate human rights (ECHR, 2007; ECHR, 2003; ECHR, 2009). The concept of environmental democracy has been outlined where the Court encourages the public to participate in decision-making with the corresponding obligation to take into account individuals' views (ECHR, 2004) and the results of researches should become available to the public (Boisson de Chazournes, 2020).

The global and regional human rights protection system makes an obvious connection between the rights to health and environment and the right to information and between the right to be heard and the rights to participation in the investment process. This means that it is impossible to develop national legislation excluding the principle of obligation of active transparency or fair balance without providing the public with the co-decision rights to inspect the programmes and investments - both public or private ones - which may affect the environment and human health. This, therefore, means that on grounds of international protection of human rights there is a need for implementation of HIA into national law as a condition sine qua non for providing a citizen with the real right to objective information. On the other hand everybody should have the opportunity to comment on obtained information and thus to have a real impact on the final concept or even a planned investment admissibility.

\section{Health Impact Assessment in the context of regional acts of international law}

\subsection{International legal basis for HIA}

The elements of HIA in international hard law should be sought primarily in the Espoo Convention (25 February 1991) on environmental impact assess- 
ment in a transboundary context and in the supplementary Kiev Protocol on the Strategic Environmental Assessment on 21 May 2003, in Aarchus Convention on 25 June 1998 and in the Escazu Agreement on 4 March 2018 (the Regional Agreement aiming to guarantee the full and effective implementation in Latin America and the Caribbean of the rights of access to environmental information, public participation in the environmental decision-making and access to justice in environmental matters).

These international law acts create regional systems justifying HIA because of the public and private investments.

The Environmental Impact Assessment (EIA) issues have been first covered in the Espoo Convention and then in the Kiev Protocol. This Convention defines an impact in Article 1 viii (Espoo, 1991) as any effect caused by a proposed activity on the environment including human health and safety, flora, fauna, soil, air, water, climate, landscape, and historical monuments or other physical structures or the interaction among these factors; it also includes effects on cultural heritage or socio-economic conditions resulting from alterations to those factors. Similarly an impact is defined in the Kiev Protocol in Article 2.7 (Kiev, 2003) where environmental including health effect means any effect on the environment, including human health. This impact as developed in the Convention refers by definition to human health. According to the abovementioned definition the sound carrying out of the Environmental Impact Assessment procedure is not possible without HIA. The Aarchus Convention refers also to it indicating that every person has the right to live in an environment adequate to his or her health and well-being, and the duty, both individually and in association with others, to protect and improve the environment for the benefit of present and future generations. The Convention indicates that the state of human health and safety (Article $2.3 \mathrm{c}$ of the Convention) is environmental information and that the way in which public authority make it available to the public is transparent and effectively accessible (Article 5.2 of the Convention) (Aarhus, 1998). This means that the same information should be available in the field of health impact. Both conventions consider human health as a part of the environmental and public access to information as a condition sine qua non of achieving sustainable development objectives.

The decision III/8 adopted by the Parties of the Espoo Convention contains guidelines for public participation in Environmental Impact Assessment pointing to the need for active participation of citizens in the whole investment process. It reminds that Principle 10 of United Nations Conference on Environment and Development (UNCED) in Rio de Janeiro, (Brazil, 3-14 June 1992), underlines that environmental issues are best handled with the participation of all concerned citizens at the relevant level.
Agenda 21 adopted by UNCED recognized the important role of broad, public participation in EIA as one of the fundamental prerequisites for the achievement of sustainable development. A public debate on the suggested actions for all interested groups in the early-decision making process may prevent or mitigate conflicts and negative environmental impact of decisions with cross-border effect. The same should also apply to the public participation in drawing up plans and public programmes under the Kiev Protocol (Cavtat, 2004). As previously indicated an impact under the Espoo Convention is considered as every impact on human health. The abovementioned decision extends to human health impacts in accordance with point 2.1 of Decision III/8 where it is recommended that at least the national procedures of Environmental Impact Assessment include regulations ensuring that:

a) the public is informed of all proposals on activities potentially harmful to the environment in cases subject to the EIA procedure in order to obtain a permit to act;

b) the public in areas which may be affected is entitled to express comments and opinions on proposed action when all options are open before a final decision is taken;

c) reasonable time-frames for providing enough time for each of various stages of public participation in the EIA shall be ensured;

d) making a final decision on the proposed actions, public participation results in the EIA procedure are duly taken into account.

A real need to inform on health impact is required explicitly by the Escazu Convention adopted on 4 March 2018 in Escazu, Costa Rica. This Convention open for 33 States of Latin America and Caribbean has been signed by 9 states so far and has not yet entered into force. Nevertheless, with respect to Health Impact Assessment, it constitutes a significant novum, introducing this concept into international law. Each party shall guarantee mechanisms for the participation of the public in decision-making processes revisions, re-examinations or updates with respect to projects and activities and in other processes for granting environmental permits that have or may have a significant impact on the environment, including when they may affect health (Article 7 (2) of the Convention). The Convention defines Environmental Information as any information related to environmental risks, and any possible adverse impacts affecting or likely to affect the environment and health, as well as to environmental protection and management (Article $2 \mathrm{c}$ of the Convention). In accordance with that legal act, the parties guarantee that consumers and users have formal, clear and relevant information on environmental goods and services, their impact on health and promoting sustainable patterns of production and consumption. Exam- 
ining this Convention one could carefully risk saying, that as it stands, the institution of Health Impact Assessment is for the first time clearly justified under international law (Escazú Convention, 2018).

The need to develop Environmental Impact Assessment including the elements of human health was strongly emphasised in the case-law of the International Court of Justice. That Court referred at least twice to environmental issues in its case-law: for the first time in Advisory Opinion of 1996 recognizing that the environment is not an abstraction but represents the living space, the quality of life and the very health of human beings, including generations unborn. The existence of the general obligation of States to ensure that activities within their jurisdiction and control respect the environment of other States or of areas beyond national control is now part of the corpus of international law relating to the environment (ICJ Advisory Opinion, 1996).

The Court of Justice in the judgement in the case Argentina v. Uruguay, where each of the states were not party to the Convention, referred directly to the environmental impact not only as a concept and inter partes proceedings resulting from the Espoo Convention but as an element of ordinary, international law. In the justification to the judgement the Court held that a practise, which in recent years has gained so much acceptance among States that it may now be considered a requirement under general international law is to undertake an environmental impact assessment where there is a risk that the proposed industrial activity may have a significant, adverse impact in a transboundary context, in particular, on a shared resource (ICJ Judgment, 2010). It means that the procedure of EIA is considered a principle of international law on an erga omnes basis (Boyle, 2012), and the doctrine indicated that such an approach of the Court to environmental rights has already been stated (Stec, 1998). Taking account of Article 38 of the Statute of the International Court of Justice it should be pointed out that the obligation to carry out the Environmental Impact Assessment procedure in the investment process at the international level is one of the fundamental principles of international law (ICJ Statute, 1945).

\subsection{Health Impact Assessment in the context of the} implementation of international law to the European legal order.

In European Union (EU) the institutions of Health Impact Assessment and of Access to Environmental Information are implemented by EU Directives:

a) Directive 2011/92/EU of the European Parliament and of the Council of 13 December 2011 on the assessment of the effects of certain public and private projects on the environment (EIA Directive, 2011);

b) Directive 2001/42/EC of the European Parliament and of the Council of 27 June 2001 on the assessment of the effects of certain plans and programmes on the environment (SEA Directive, 2001);

c) Regulation (EC) No 1367/2006 of the European Parliament and of the Council of 6 September 2006 on the application of the provisions of the Aarchus Convention on Access to Information, Public Participation in Decision-making and Access to Justice in Environmental Matters to Community institutions and bodies (Regulation (EC), 2006).

Directive 2011/92/EU called also the Environmental Impact Assessment Directive indicates that the environmental legislation of the Union includes regulations enabling public authorities and other bodies to take decisions which may have a significant effect on the environment as well as on person health and wellbeing (Directive, 2011). It means that effects of the project on the environment should be assessed in order to take account of concerns to protect human health, to contribute by means of a better environment to the quality of life, to ensure maintenance of the diversity of species and to maintain the reproductive capacity of the ecosystem as a basic resource for life. Environmental Impact Assessment in accordance with Article 3 should include description and assessment of direct and indirect effects of the project on humans that cannot be conducted properly without the impact of the investment on human health. The results of the public consultations and information collected during the procedure have to be taken into consideration by the state in the investment decision procedure. The Directive prejudges the final form of its implementation into the national legal order in the way that it is not possible to skip comments from local people or just ignore them. The same approach is adopted by the SEA (SEA Directive, 2001). Directive which points out the criteria of the potential, significant environmental effects where threat to health is one of them, requiring in such a case the implementation of the Strategic Environmental Impact Assessment. This is due to the information that must be submitted by entities referred to in Article 5(3) of the SEA Directive and which should include, but not be limited to, the likely significant effect on the environment, including on issues such as biodiversity, population, human health, fauna, flora, soil, water, air, climatic factors, material assets, cultural heritage, including architectural and archaeological heritage, landscape and the interrelationship between the above factors. Therefore, undertaking HIA should not be questionable in terms of plans and programmes which may always have a significant impact on the environment. The connection between the state of the environment and human health and the need to assess the planned investment were subjects to legal proceedings held by the Court of Justice of the European Union. In a previous opinion of 13 July 20014, the Advocate General of the CJEU indicates that it derives from points 
4 and 14 of the EIA Directive that by this assessment it is necessary to achieve the objectives of the Union regarding the environmental protection and the quality of life (EIA Directive, 2011). The effects of the project on the environment should be assessed in order to take account of concerns to protect human health, to contribute by means of a better environment to the quality of life and to maintain the reproductive capacity of the ecosystem as a basic resource for life. The issue of human health protection from the adverse impacts of the environment was repeatedly cited by the Court as the (additional) prerequisite which enables an individual to refer to the regulations of the European Union law, capable of direct application, on environmental protection (Curia, 2014). In the abovementioned opinion, the Advocate General also points to the fact that the EIA Directive from its supplementation by Directive 2003/35 is intended to adapt the EU law to the Aarchus Convention. Therefore, the EIA Directive must be interpreted both in the light of the Aarchus Convention and while taking account of its objectives. As mentioned in recital 7 of the Aarchus Convention every person has the right to live in an environment adequate to his or her health and well-being, and the duty, both individually and in association with others, to protect and improve the environment for the benefit of present and future generations. As mentioned in recital 8 , to be able to assert this right and observe this duty, citizens must be entitled to participate in decision-making and have access to justice in environmental matters.

The Court of Justice commented positively on the linkage of HIA and EIA for example in the judgement of 14 March 2013 (Leth v. Austria, C-420/11) where noted that from Article 1(1) of Directive $85 / 337$ and also from recitals 1, 3, 5, 6 it follows that this Directive shall apply to the assessment of the effects of certain public and private projects on the environment whereas it is necessary to achieve one of the Community's tasks in the sphere of the protection of the environment and the quality of life. To meet this requirement a developer should supply the information specified in Article 5(1) and in Annex IV to Directive. The criteria for assessing whether minor project, referred to in Annex III to Directive, must be subjected to EIA, serve the same purpose. It follows from recitals 3 and 11 to Directive 85/337 that it is necessary to achieve one of the Union's objectives in the sphere of the protection of the environment and the quality of life and the effects of the project on the environment must be assessed in order to take account of concerns to contribute by means of a better environment to the quality of life (Curia, 2013).

The transposition of international law into the EU law has effectively introduced the link between the environment and human health. An environmental impact assessment of a project or a programme must not be carried out without taking into consideration health effects of a project. The Court of Justice of European Union also points out that health and environmental issues should not be resolved separately. In practice, this means implementation of the postulates of European Charter on Environment and Health adopted by Ministers of the Environment and Health of the Member States of the European Region of WHO meeting together for the first time at Frankfurt-am-Main on 7 and 8 December 1989. The Preamble of the Charter recognized the dependence of human health on a wide range of crucial environmental factors and entitled every individual of EU to information and consultation on the state of the environment, and on plans, decisions and activities likely to affect both the environment and health (WHO Europe, 1989). Last but not least it falls to be considered the place of HIA in the light of Agenda 2030. Agenda 16 aims to promote peaceful and inclusive societies for sustainable development, provide access to justice for all and build effective, accountable and inclusive institutions at all levels. Within this objective a task 16.10 defined as Ensure public access to information and protect fundamental freedoms, in accordance with national legislation and international agreements is foreseen. In favour of linking the right to information with the right to health indicates also SDG Good Practise A Compilation of success stories and lessons learned in SDG implementation (UN Resolution, 2015).

\section{Conclusion}

International law does not clearly say about the institution of HIA, however, it can be drawn from a series of legal standards scattered across a number of different instruments of international law. Primarily it should be noted that there are obvious correlations between the environment and both human and public health. There is now a political will to strengthen the links between the environment and human health expressed in the numerous documents of the Conferences organised under the auspices of WHO (Conferences in Alma-Ata, Ottawa, Sundsvall, Adelaide, Bangkok, Nairobi) and the United Nations (Stockholm, Rio de Janeiro, Johannesburg). This will is reflected in such interpretation of global regulations for the Protection of Human Rights which the right to live in a healthy environment derive from the human right to life, health, information and from the right to be heard. The right to healthy environment and to information cannot be carried out without the right to information about the health impact of investments or planning. This approach has been reflected in the regional systems of human rights protection and is shared by the Inter-American Court of Human Rights and the European Court of Human Rights. This means that the adoption by national legal order measures eliminating or reducing the institution of Health Impact Assessment, whilst implementing the investment that might affect it, may be 
considered by international justice as violating human rights to life or to privacy.

The case-law of the International Court of Justice has raised the profile of Environmental Impact Assessment of an investment having cross-border effects from inter partes towards erga omnes inserting it into international ordinary law, not related to the Treaties.

The availability of integrated, relevant, high-quality, timely and easily accessible environmental information provides the means for assessing environmental status and the foundation for meaningful and informed environmental governance. Timely, relevant, reliable and easily accessible environmental information is also essential to efforts to inform citizens about the quality of their environment, raising their awareness in that regard and enabling them to defend their basic right to live in a healthy and safe environment (UNECE, 2020).

Health Impact Assessment must be important part of EIA, so in view of these circumstances, it is inadmissible for an impact assessment not to be carried out even if it were not available in the national legal order. This right is part of general international law and the corpus of human rights that is the right to life, and it can never be derogated.

\section{References}

1. AARHUS, 1998, Convention on Access to Information, Public Participation in Decision-making and Access to Justice in Environmental Matters (Aarhus Convention), Official Journal, L 124: 0004-0020.

2. ACHR SAN JOSE, 1969, American Convention on Human Rights, San Jose, Costarica.

3. ADELAIDE, 1988, Second International Conference on Health Promotion, Adelaide, South Australia, 5-9 April, https://www.who.int/healthpromotion/conferences/previous/adelaide/en/ (20.06.2020).

4. ADVISORY OPINION, 2017, OC 23/17 of November 15, on the application from Colombia regarding state obligations with regard to the environment in the context of protection and guarantee of the right to personal life and integrity: interpretation and scope of Art. 4.1 and art. 5.1 in relation to Art. 1 (1-2) of the Inter-American Convention on Human Rights, http:// hrlibrary.umn.edu/iachr/iachr.html (17.07.2020).

5. ALMA-ATA, 1978, Declaration of Alma-Ata International Conference on Primary Health Care, AlmaAta, USSR, 6-12 September, https://www.who.int /publications/almaata_declaration_en.pdf (20.06.2020).

6. BANGKOK, 2005, The 6th Global Conference on Health Promotion, Thailand, August, https://www. who.int/healthpromotion/conferences/6gchp/hpr_05 0829_\%20BCHP.pdf (20.06.2020).

7. BANJUL CHARTER, 1981, The African (Banjul) Charter on Human and Peoples' Rights, Nairobi, https://www.achpr.org/legalinstruments/detail?id=49 (20.06.2020).

8. BOISSON DE CHAZOURNES L, 2020, Opening of the Judicial Year of European Court of Human Rights Environment Human rights and the environment: an evolving relationship Seminar 31.01, Strasbourg,
https://echr.coe.int/Documents/Speech_20200131_ Boisson_de_Chazournes_JY_ENG.pdf (17.07.2020).

9. BOYLE A., 2012, Developments in International Law of EIA and their Relation to the Espoo Convention, https://www.unece.org/fileadmin/DAM/env/eia /documents/mop5/Seminar_Boyle.pdf (18.07.2020).

10. CAVTAT, 2004, Meeting of parts of Espoo Convention in Cavtat, Guidance on Public Participation The third meeting of the Parties of Espoo Convention Desision III/8, https://www.unece.org/env/eia/pubs/ publicpart_guidance.html (18.07.2020).

11. CURIA, 2013, Judgment of the Court (Fourth Chamber), 14 March 2013 Jutta Leth v Republik Österreich, Land Niederösterreich C-420/11, http://curia.europa.eu/juris/liste.jsf?num=C-420/11\&languag $\mathrm{e}=\mathrm{EN}(18.07 .2020)$.

12. CURIA, 2014, Advocate General's opinion C570/13, https://eur-lex.europa.eu/legal-content/GA/ TXT/?uri=CELEX:62013CC0570 (24.01.2021).

13. ECHR, 2003, Decisions of European Court of Human Rights, Jul 8, Hatton and Others v. the United Kingdom \& 128 Reference number 36022/97, https://hudoc.echr.coe.int/eng\#\{\%22itemid\%22:[\%22001-611 $88 \% 22]\}$ (20.06.2020).

14. ECHR, 2004, Decisions of European Court of Human Rights, Nov 10, Tasking and Others v. Turkey Reference number 46117/99, \$118, http://worldlii.org/eu/cases/ECHR/2004/621.html (20.06.2020).

15. ECHR, 2007, Decisions of European Court of Human Rights, March 26, Giacomelliv. Italy. \$83; Reference number 59909/00, http://www.ecolex.org/8984/ server2neu.php/libcat/docs/COU/Full/En/COU157044.pdf (20.06.2020).

16. ECHR, 2009, Decisions of European Court of Human Rights, January 27, Affaire Tătar v. Roumanie, $\$ 101$ Reference number 67021/01, https://hudoc.echr.coe. int/eng\#\{\%22itemid\%22:[\%22001-90909\%22]\} (20.06.2020).

17. EIA DIRECTIVE, 2011, Directive 2011/92/EU of the European Parliament and of the Council of $13 \mathrm{De}$ cember 2011 on the assessment of the effects of certain public and private projects on the environment, EUR-Lex-32011L0092-EN-EUR-Lex.

18. ESCAZÚ CONVENTION, 2018, Regional Agreement on Access to Information, Public Participation and Justice in Environmental Matters in Latin America and the Caribbean Escazú, 4 March, https://treaties.un.org/doc/Treaties/2018/03/20180312\%2003-0 4\%20PM/CTC-XXVII-18.pdf (18.07.2020).

19. ESPOO, 1991, Convention on Environmental Impact Assessment in a Transboundary Context, done at Espoo on February 25, (Espoo Convention), Journal of Laws 1999, No 96 item 1110.

20. GOETHEBORG, 1999, WHO European Centre for Health Policy, Health Impact Assessment: main concepts and suggested approach - Gothenburg consensus paper, WHO European Centre for Health Policy, Brussels, http://rbus-eis.org/pdf/Consensus_de_Gotborg.pdf (20.06.2020).

21. HELSINKI, 2013, The 8th Global Conference on Health Promotion, Finland, 10-14 June, https:// www.who.int/healthpromotion/conferences/8gchp/ 8gchp_helsinki_statement.pdf (20.06.2020).

22. ICCPR, 1966, UN Resolution 2200A (XXI) December 16, International Covenant on Civil and Political Rights, UN. 
23. ICJ ADVISORY OPINION, 1996, Legality of the Threut or Use of Nuclear Weapons, Advisory Opinion, I.C.J. Reports: 241-242, § 29, https://www.icjcij.org/public/files/case-related/95/7497.pdf (18.07.2020).

24. ICJ JUDGMENT, 2010, International Court of Justice, Judgment of 20 April, Pulp Mills on the River Uruguay (Argentina v. Uruguay), https://www.icjcij.org/en/case/135/judgments (18.07.2020).

25. ICJ STATUTE, 1945, Statute of the International Court of Justice, http://www.icj-cij.org/en/statute, (3.01.2021)

26. IPESCR, 1966, UN Resolution 2200A (XXI) December 16, International Pact on Economic, Social and Cultural rights, UN.

27. JAKARTA, 1997, The Fourth International Conference on Health Promotion: New Players for a New Era - Leading Health Promotion into the 21st Century, meeting in Jakarta from 21 to 25 July, https:// www.who.int/healthpromotion/conferences/previous /jakarta/declaration/en/ (20.06.2020).

28. JENSEN G.K., STAUFLER A., ZANDER E., MICHALAK W., PULJIC V.M., 2020, Lignite health effects and recommendations for the healthcare sector, HEAL :7-9.

29. KIESSLING K.L., 1998, Conference on the Aral Sea: Women, Children, Health and Environment, Ambio, 27(7): 562.

30. KIEV, 2003, Protocol on Strategic Environmental Assessment to the Convention on Environmental Impact Assessment in a Transboundary Context, drawn up in Kiev on May 21, Kiev.

31. MALL I., VAN DER MEER J., UPSHUR R.E.G., 2001, Acting on an Environmental Health Disaster: The Case of the Aral Sea, Environmental Health Perspectives, 109(6): 547-548.

32. MEXICO, 2000, Fifth Global Conference on Health Promotion, Health Promotion: Bridging the Equity Gap, Mexico City, June 5th, https://www.who. int/healthpromotion/conferences/previous/mexico/ statement/en/ (20.06.2020).

33. MOWBRAY A., 2010, A Study of the Principle of Fair Balance in the Jurisprudence of the European Court of Human Rights, Human Rights Law Review, 10(2): 289-317. DOI: 10.1093/hrlr/ngq006.

34. NEW YORK, 1946, Constitution of the World Health Organization, https://www.who.int/governance/eb/ who_constitution_en.pdf (17.07.2020).

35. OTTAWA, 1986, The 1st International Conference on Health Promotion, Ottawa charter for health promotion, https://www.who.int/publications/i/item/ottawa-charter-for-health-promotion (20.06.2020).

36. PRZYBYTEK J., 2015, In Szopienice, children ate lead. The doctor waged war on the system, https://dziennikzachodni.pl/w-szopienicach-dzieci-jadly-olowlekarka-wydala-wojne-systemowi-historia-dz/ar/377 6395 (20.06.2020).
37. REGULATION (EC), 2006, Regulation (EC) No 1367/2006 of the European Parliament and of the Council of 6 September 2006 on the application of the provisions of the Aarhus Convention on Access to Information, Public Participation in Decision-making and Access to Justice in Environmental Matters to Community institutions and bodies, https://eurlex.europa.eu/legal-content/EN/TXT/PDF/?uri=CEL EX:32006R1367\&from $=$ EN (24.01.2021).

38. RIO, 2011, Rio Political Declaration on Social Determinants of Health, https://www.who.int/sdhconference/declaration/en/ (20.06.2020).

39. ROME, 1950, Convention on Human Rights and Fundamental Freedoms, Rome.

40. SEA DIRECTIVE, 2001, Directive 2001/42/EC of the European Parliament and of the Council of 27 June 2001 on the assessment of the effects of certain plans and programmes on the environment, EC.

41. STEC S., 1998, Of Solemn Oaths and Obligations: TheEnvironmental Impact of the ICJ'S Decision in the Case of the Gabcikovo-Nagymaros Project, https://pdfs.semanticscholar.org/06de/60cfaedd66c7 429ce8f0aefa0b325d184f07.pdf (18.07.2020).

42. SUNDSVALL, 1991, Third International Conference on Health Promotion, Sundsvall, Sweden, 9-15 June, https://www.who.int/healthpromotion/conferences/previous/sundsvall/en (20.06.2020).

43. STOCKHOLM, 1972, Raport of United Nations Conference on the Human Environment, https://www.un. org/ga/search/view_doc.asp?symbol=A/CONF.48/1 4/REV.1 (20.06.2020).

44. UDHR, 1948, Universal Declaration of Human Rights Paris, UN.

45. UNECE, 2020, Guidelines on the Shared Environmental Information System reporting mechanism, United Nations, Geneva, https://unece.org/sites/default/files/2020-12/2014795E_WEB.pdf (3.01.2021).

46. UN ECONOMIC AND SOCIAL COUNCIL GENEVA, 2000, Commitee on Economic, Social and Cultural Rights, General Comment No. 14, The right to the highest attainable standard of health (article 12 of the International Covenant on Economic, Social and Cultural Rights), http://docstore.ohchr.org/SelfServices/FilesHandler.ash $x$ ?enc=4slQ6QSmlBEDzF EovLCuW1AVC1NkPsgUedPIF1vfPMJ2c7ey6Paz2 q aojTzDJmC0y\%2B9t\%2BsAtGDNzdEqA6SuP2r0 w\%2F6sVBGTpvTSCbiOr4XVFTqhQY65auTFbQ RPWNDxL (17.07.2020).

47. UN RESOLUTION, 2015, Resolution No. A/RES/70/1.

48. WHO EUROPE, 1989, European Charter on Environment and Health, https://www.euro.who.int/ en/publications/policy-documents/european-charteron-environment-and-health,-1989

(18.07.2020). 